\title{
E-Government dengan Pemanfaatan Web OpenSID dalam Pelayanan Publik di Nagari Tanjung Haro Sikabu-kabu Padang Panjang
}

\author{
${ }^{1}$ Hazid Jalma, ${ }^{2}$ Roni Ekha Putera, ${ }^{3}$ Kusdarini \\ ${ }^{123}$ Jurusan Administrasi Publik,Fakultas Ilmu Sosial dan Ilmu Politik \\ Universitas Andalas, Padang, Indonesia \\ Email:hazidj16@gmail.com,roniekhaputera@soc.unand.ac.id, kusdarini@soc.unand.ac.id
}

Received: 7 Mei 2019; Revised: 12 Mei 2019; Accepted: 15 Mei 2019

\begin{abstract}
As a form of e-Government development initiative, Nagari Tanjung Haro Sikabu-kabu Padang Panjang has an initiative in the form of using the OpenSID web application. But in its implementation, there are still shortcomings and problems in the OpenSID implementation process. This research was conducted using qualitative descriptive methods. Data were collected through interviews with respondents selected based on purposive sampling technique, documents on the use of OpenSID web and observing the use of OpenSID web on improving public services. The study show that the use of the OpenSID web in improving public services has gone well, can be seen from the dimensions of public sector web analysis. Utilization of the OpenSID web has various information and is managed well with the PPID. The impact of public services that can be felt from the use of the OpenSID web is to easily obtain nagari information, information on public service processes and public services that can be resolved quickly because of population data that already exists on the OpenSID server. However, the utilization of the OpenSID website is still not running optimally. This is because some of the information contained in the content is non-updated information and some information does not yet exist.
\end{abstract}

Keywords: E-Government; OpenSID; Village Government.

\begin{abstract}
Abstrak
Sebagai bentuk inisiatif pengembangan e-Government, Nagari Tanjung Haro Sikabu-kabu Padang Panjang memiliki inisiatif dalam bentuk menggunakan aplikasi web OpenSID. Namun dalam implementasinya, masih ada kekurangan dan masalah dalam proses implementasi OpenSID. Penelitian ini dilakukan dengan menggunakan metode deskriptif kualitatif. Data dikumpulkan melalui wawancara dengan responden yang dipilih berdasarkan teknik purposive sampling, dokumen tentang penggunaan web OpenSID dan mengamati penggunaan web OpenSID untuk meningkatkan layanan publik. Studi ini menunjukkan bahwa penggunaan web OpenSID dalam meningkatkan layanan publik telah berjalan dengan baik, dapat dilihat dari dimensi analisis web sektor publik. Pemanfaatan web OpenSID memiliki berbagai informasi dan dikelola dengan baik dengan PPID. Dampak dari layanan publik yang dapat dirasakan dari penggunaan web OpenSID adalah dengan mudah mendapatkan informasi nagari, informasi tentang proses layanan publik dan layanan publik yang dapat diselesaikan dengan cepat karena data populasi yang sudah ada di server OpenSID. Namun, pemanfaatan situs web OpenSID masih belum berjalan optimal. Ini karena beberapa informasi yang terkandung dalam konten adalah informasi yang tidak diperbarui dan beberapa informasi belum ada.
\end{abstract}

Kata Kunci : E-Government; OpenSID; Pemerintahan Desa

Link DOI : http://dx.doi.org/10.31314/pjia.8.1.24-37.2019

24 Copyright $@$ C 2019, Publik (Jurnal Ilmu Administrasi), Under the license CC BY-SA 4.0 ISSN: 2301-573X (Print), ISSN: 2581-2084 (Online) 
Publik (Jurnal Ilmu Administrasi) Vol 8 (1), Juni 2019

PENDAHULUAN

Pemanfaatan internet oleh orangorang disekitar sekarang sering kali kita jumpai dalam berbagai kegiatan yang kita lakukan sehari-hari. Sebuah asosiasi yang menaungi penyelenggaraan internet di Indonesia, yaitu Asosiasi Penyelenggara Jasa Internet Indonesia (APJII) mencatat pertumbuhan penggunaan internet $\mathrm{di}$ Indonesia seperti gambar 1

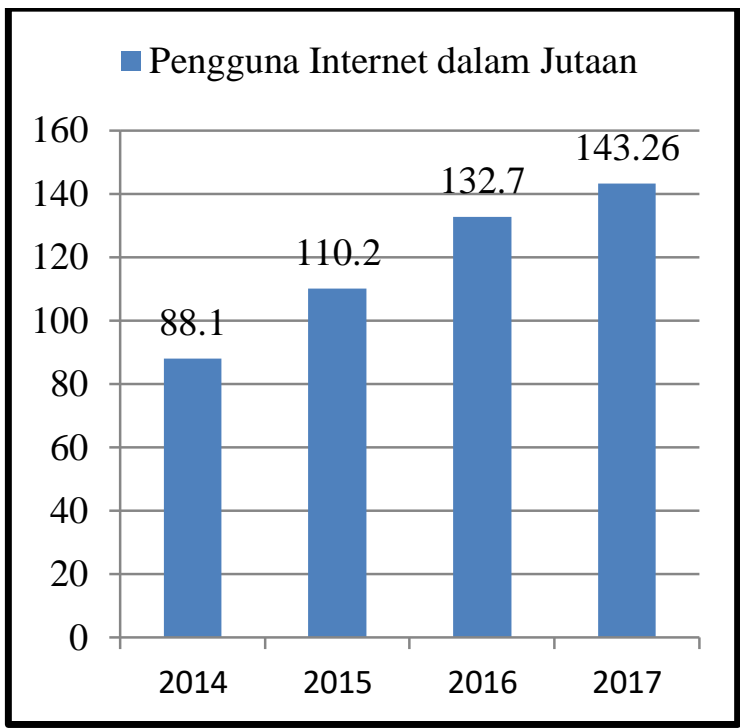

Sumber : APJII (Survei Penetrasi dan Perilaku Pengguna Internet Indonesia 2017)

\section{Gambar 1}

\section{Pertumbuhan Pengguna Internet}

Gambar 1 yang telah ditampilkan menggambarkan terjadinya peningkatan pengguna internet di Indonesia setiap tahunnya. Tercatat pada tahun 2017 dari 262 juta orang populasi penduduk Indonesia, 143,26 juta orang atau 54,68\% merupakan pengguna internet. Karena internet merupakan sarana penghubung penggunaan teknologi, tentu dapat disimpulkan bahwa penggunaan teknologi di masyarakat mengalami peningkatan. Peningkatan pemanfaatan teknologi di masyarakat sudah selayaknya dimanfaatkan oleh pemerintah untuk dapat meningkatkan hubungan pemerintah dengan masyarakat terutama pada pelayanan publik. Karena pelayanan publik merupakan pemenuhan kebutuhan yang dilakukan pemerintah kepada masyarakat. Sebagaimana menurut Undang-undang Nomor 25 Tahun 2009 tentang Pelayanan Publik, pelayanan publik adalah kegiatan atau rangkaian dalam rangka pemenuhan kebutuhan pelayanan sesuai dengan peraturan perundang-undangan bagi setiap warga negara dan penduduk atas barang, jasa, dan/atau pelayanan administratif yang disediakan oleh penyelenggara publik. Pelayanan kepada masyarakat sudah menjadi tujuan utama dalam penyelenggaraan administrasi publik. Pelayanan publik yang baik merupakan hal wajib dipenuhi pada setiap organisasi kerja baik Pemerintah maupun swasta (Mohi,WK \& Mahmud,I, 2018).

Pergeseran pelayanan publik dengan menggunakan teknologi tentu membutuhkan inovasi yang dilakukan oleh pemerintah terhadap pelayanan publik. Inovasi pelayanan publik adalah terobosan pelayanan publik yang merupakan gagasan ide kreatif original dan adaptasi/modifikasi memberikan manfaat bagi masyarakat baik secara langsung maupun tidak langsung. Dengan kata lain, inovasi pelayanan publik sendiri tidak mengharuskan suatu penemuan baru, tetapi dapat merupakan suatu pendekatan baru yang bersifat kontekstual dalam arti inovasi tidak terbatas dari tidak ada kemudian muncul gagasan dan praktik inovasi, tetapi dapat berupa inovasi hasil dari perluasan maupun peningkatan kualitas pada inovasi yang ada. Pandangan mengenai inovasi pada sektor yang berhasil merupakan hasil kreasi dan implementasi proses, produk layanan, dan metode baru dan juga hasil dari pengembangan nyata dari efisiensi, efektivitas, dan kualitas hasil (Muluk, 2008). Adanya Peraturan Menteri Pendayagunaan Aparatur Negara dan 
Reformasi Birokrasi (Permenpan-RB) Nomor 30 Tahun 2014 tentang Pedoman Inovasi Pelayanan Publik, tentu mempermudah penyelenggara pelayanan publik dalam mengupayakan terealisasinya inovasi pelayanan publik dalam upaya meningkatkan kualitas pelayanan publik.

Sejalan dengan inovasi pelayanan publik menggunakan teknologi, Menteri Pendayagunaan Aparatur Negara dan Reformasi Birokrasi (Menpan-RB) mengatakan, saat ini Indonesia memasuki era Connectivity and Internet of Think, dimana batasan ruang diterjang dan waktu dipersingkat, kemudian juga dalam tata kelola pemerintahan penerapan sistem pemerintahan berbasis elektronik atau yang lebih dikenal dengan $e$ Government (Electronic Government) adalah sebuah keniscayaan. Kementerian Pendayagunaan Aparatur Negara dan Reformasi Birokrasi sebagai penggerak utama reformasi birokrasi, menyadari betul pentingnya peningkatan efisiensi, efektivitas dan akuntabilitas dalam tata kelola pemerintahan di era digital menuju terwujudnya pemerintahan kelas dunia (Suara.com, 2018).

Penggunaan teknologi informasi dan komunikasi menjadi sangat penting dalam era globalisasi sekarang ini, karena dapat menembus jarak yang jauh bahkan melampaui batas negara sekalipun. Seiring dengan hal tersebut, kemudian melahirkan istilah dan konsep baru di negara indonesia, yaitu apa yang biasa disebut dengan Electronic Government (eGovernment) yang diwujudkan sebagai penerapan penggunaan teknologi informasi dan komunikasi dalam pemerintahan(Prasetyo, n.d.). Berdasarkan definisi e-Government menurut World Bank, e-Government adalah penggunaan teknologi informasi oleh pemerintah seperti: Wide Area Network, Internet, dan Mobile Computing yang memungkinkan pemerintah untuk mentransformasikan hubungan dengan masyarakat, dunia bisnis, dan pihak yang berkepentingan(Indrajit, 2005).

Beberapa manfaat e-Government adalah (1) menurunkan biaya administrasi; (2) meningkatkan kemampuan response terhadap berbagai permintaan dan pertanyaan tentang pelayanan publik baik dari sisi kecepatan maupun akurasi; (3) dapat menyediakan akses pelayanan untuk semua departemen atau LPND pada semua tingkatan; (4) memberikan asistensi kepada ekonomi lokal maupun secara nasional; (5) sebagai sarana untuk menyalurkan umpan balik secara bebas, tanpa perlu rasa takut (Satriya, 2006).

E-Government diselenggarakan oleh pemerintahan bertujuan agar Indonesia tidak tertinggal dari negara-negara lain dalam persaingan global. Banyak hal yang bermanfaat dapat diperoleh seperti efektive dan efisien apabila pemerintah menggunakan teknologi sebagai pembantu untuk mempermudah pelaksanaan penyelenggaraan pemerintahan(Ramdhani \& Ramdhani, 2017). Bukti perhatian pemerintah terhadap penggunaan teknologi dengan adanya Instruksi Presiden Nomor 6 Tahun 2001 tentang Pengembangan dan Pendayagunaan Telematika di Indonesia. Salah satu konsep yang menjadi fokus dalam Inpres tersebut adalah pengembangan information and communications technology (ICT). Konsep inilah yang menyokong berkembangnya aplikasi e-Government di Indonesia.

Setelah keluarnya Instruksi Presiden Nomor 6 Tahun 2001, dilanjutkan dengan kebijakan yang lebih fokus dalam pelaksanaan e-Government melalui Instruksi Presiden Nomor 3 Tahun 2003 
Publik (Jurnal Ilmu Administrasi) Vol 8 (1), Juni 2019

tentang Kebijakan dan Strategi Nasional Pengembangan e-Government. Menurut Instruksi Presiden Nomor 3 Tahun 2003, bahwa pengembangan e-Government merupakan upaya untuk mengembangkan penyelenggaraan kepemerintahan yang berbasis elekronik dalam rangka meningkatkan kualitas pelayanan publik secara efektif dan efisien. Melalui pengembangan e-Government dilakukan penataan sistem manajemen dan proses kerja dilingkungan pemerintahan dengan mengoptimalkan pemanfaatan teknologi informasi.

Pemerintah melihat penerapan teknologi dalam melaksanakan pemerintahan merupakan suatu yang penting, sehingga dengan adanya Instruksi Presiden Nomor 3 Tahun 2003 mendukung terciptanya langkah-langkah konkret yang diperlukan sesuai dengan tugas, fungsi dan wewenang pemerintah pusat maupun daerah agar terlaksananya pengembangan e-Government secara nasional. MenpanRB mengatakan berjanji mulai menerapkan sistem pemerintah berbasis elektronik atau e-Government secara nasional tahun 2018. Adanya sistem pemerintahan secara nasional ini diyakini bisa menghadirkan efisiensi belanja information tecnology (IT) yang dikeluarkan selama ini. Sistem yang sudah ada di daerah akan direplikasi untuk penerapan e-Government secara nasional.

Instansi Pemerintah pada Kantor Kepala Desa merupakan suatu instansi melakukan pendataan penduduk terutama dalam proses pembuatan Kartu Tanda Surat Kelahiran, Surat ematian, dan Surat Keterangan Pindah. Untuk dapat meningkatkan pendataan penduduk beserta laporannya kepada instansi yang lebih tinggi yaitu kecamatan, maka diperlukan langkah-langkah pengembangan sistem pendataan yang sudah berjalan dengan Penduduk (KTP), Kartu Keluarga (KK),

sistem baru dimana komputer sebagai alat bantu dalam menyelesaikan tugastugas yang berkaitan dengan pendataan penduduk sehingga setiap pekerjaan dapat diselesaikan dengan efektif dan efisien (Fahrur, 2017).

Peneliti menemukan inovasi pelayanan publik berbasis web yang dibangun melalui inisiatif pemerintah nagari di Nagari Tanjung Haro Sikabukabu Padang Panjang Kecamatan Luak Kabupaten Lima Puluh Kota Inovasi di Nagari Tanjung Haro Sikabu-kabu Padang Panjang berbentuk Standar Pelayanan Minimal berbasis digital dan Informasi Berbasis Web (OpenSID) yang diselenggarakan oleh pemerintah nagari. OpenSID adalah sebuah sistem informasi desa yang sengaja dirancang terbuka dan dapat dikembangkan secara bersama-sama oleh komunitas Peduli Sistem Informasi Desa (SID). SID yang bermakna dan bermanfaat bagi masyarakat nagari baik secara internal maupun eksternal memerlukan tidak hanya dorongan yang bersifat top down (Github.com, 2018). Pengelolaan SID yang efektif tentu dimulai dari harapan bahwasanya SID akan membantu menciptakan kehidupan masyarakat yang lebih baik, dan dilakukan sendiri oleh masyarakat (Nunik, 2016).

OpenSID dapat memudahkan pemerintah nagari dalam segala hal, karena fitur yang tersedia dalam OpenSID sudah terbilang sangat lengkap. Dalam bahasa sistem informatika, pembuatan SID ini dibuat dengan menggunakan aplikasi open source yaitu OpenSID. Arsistektur dimulai dari user dengan memasukkan alamat http, selanjutnya akan masuk pada layer interface. Pada layer interface ini terdapat ketika user masuk ke web browser. Setelah masuk, dimana pada layer ini terdapat bahasa program untuk memperbaiki tampilan web yaitu Pustaka JavaScript (Jquery), Hypertext Markup Language Copyright (c) 2019, Publik (Jurnal Ilmu Administrasi), Under the license CC BY-SA 4.0 ISSN: 2301-573X (Print), ISSN: 2581-2084 (Online) 
(HTML), dan Cascading Style Sheet (CSS). Sementara untuk inti dalam web dibuat dengan menggunakan bahasa Hypertext Prepocessor (PHP) dengan menggunakan Apache (HTTP) sebagai server. Bagian database akan digunakan Sistem Manajemen Berbasis Data (MySQL) (Fahrur, 2017).

Launcing OpenSID Nagari Tanjung Haro Sikabu-kabu Padang Panjang ini dihadiri oleh Bupati Irfendi Arbi, Kepala Organisasi Perangkat Daerah (OPD) terkait, anggota DPRD Daerah Pemilihan (Dapil) Setempat, dan unsur Musyawarah Pimpinan Kecamatan (Muspika) pada hari Selasa, 27 Februari 2018. Bupati Irfendi Arbi mengapresiasi inovasi nagari dalam mewujudkan pelayanan publik yang prima serta informasi akurat melalui aplikasi OpenSID melalui pelayanan berbasis digital dan media informasi publik berbasis web. Media aplikasi ini juga sebagai salah satu pendukung promosi obyek wisata baru di Kabupaten Lima Puluh Kota. Pemerintah Kabupaten Lima Puluh Kota senantiasa mengapresiasi dan mendukung upaya nagari dalam melakukan inovasiinovasi yang bermanfaat bagi masyarakat. Apresiasi juga diberikan oleh Pemerintah Provinsi Sumatera Barat melalui Dinas Pemberdayaan Manyarakat Desa dan Nagari. Web OpenSID Nagari Tanjung Haro Sikabu-kabu Padang Panjang Kecamatan Luak Kabupaten Lima Puluh Kota dapat diakses melalui domain https://www.tanjungharosikabukabupadang panjang.desa.id/. Masyarakat bisa mengakses informasi Nagari Tanjung Haro Sikabu-kabu Padang Panjang secara uptodate (Limapuluhkota.go.id, 2018).

Jadi, inovasi pelayanan publik dibutuhkan saat sekarang karena perubahan pola interaksi masyarakat yang disebabkan penggunaan teknologi yang terhubung dengan internet. Perubahan ini direspon oleh pemerintah dengan penggunaan e-Government yang dapat menciptakan efisiensi, efektivitas dan akuntabilatas untuk penyelenggaraan pelayanan publik. Selain itu, dengan menggunakan e-Government waktu dan jarak tidak lagi menjadi masalah dalam memperoleh pelayanan publik.

Berdasarkan penjelasan yang telah dipaparkan, peneliti tertarik untuk membahas bagaimana analisis pemanfaatan web OpenSID dalam peningkatan pelayanan publik di Nagari Tanjung Haro Sikabu-Kabu Padang Panjang Kecamatan Luak Kabupaten Lima Puluh Kota. Tulisan mengulas konsep dan teori tentang analisis web sektor publik, dengan mengangkat pembahasan mengenai bagaimana analisis pemanfaatan web OpenSID dalam peningkatan pelayanan publik di Nagari Tanjung Haro SikabuKabu Padang Panjang Kecamatan Luak Kabupaten Lima Puluh Kota?. Tulisan ini juga bertujuan untuk mendeskripsikan analisis pemanfaatan web OpenSID dalam peningkatan pelayanan publik di Nagari Tanjung Haro Sikabu-Kabu Padang Panjang Kecamatan Luak Kabupaten Lima Puluh Kota.

\section{METODE PENELITIAN}

Penelitian ini disusun dengan menggunakan kualitatif deskriptif. Tujuan dari penelitian deskriptif adalah memecahkan masalah dengan menggambarkan problematika yang terjadi dengan membuat gambaran secara sistematis, faktual dan akurat. (Caldas, 2009). Teknik pemilihan informan dalam penelitian ini adalah teknik purposive sampling. Dengan kata lain peneliti harus menentukan karakteristik dari informan terlebih dahulu, sehingga dengan demikian 
peneliti dapat mengumpulkan data yang sesuai dengan tujuan yang ingin peneliti capai.

Menurut Johnson, peneliti memaparkan dimensi-dimensi dimana variabilitas dicari, kemudian mengambil informan yang memiliki pengetahuan yang sesuai dengan diteliti. Tujuannya adalah untuk menemukan orang-orang yang lebih berpengetahuan, andal, dan akurat dalam melaporkan peristiwa-peristiwa yanh sedang diteliti oleh peneliti (Miles, M.B \& Huberman, 1994). Dengan desain ini diharapkan dapat diperoleh pemahaman yang valid mengenai analisis pemanfaatan web OpenSID dalam peningkatan pelayanan publik di Nagari Tanjung Haro Sikabu-kabu Padang Panjang Kecamatan Luak Kabupaten Lima Puluh Kota. Sedangkan data dan informasi yang dihadirkan dalam tulisan ini merupakan data yang diambil dari wawancara adalah seni bersosialisasi, pertemuan dua manusia yang saling berinteraksi dalam jangka waktu tertentu berdasarkan kesetaraan status, terlepas apakah hal itu benar-benar kejadian nyata atau tidak (Crozier, Denzin, \& Lincoln, 1994), dokumentasi dan observasi yang kemudian dianalisis.

\section{HASIL DAN PEMBAHASAN}

\section{Dimensi Analisis Web Sektor Publik}

Secara potensial, penggunaan teknologi web dapat membantu mengumpulkan saran dari masyarakat untuk meningkatkan pembuatan kebijakan, menghasilkan transparansi dan kepercayaan kepada pemerintah dan meningkatkan hubungan antara pemerintah dan masyarakat. Studi tentang situs web dalam administrasi publik telah semakin luas dalam literatur sejak akhir 1990-an. Sampai sekarang tidak ada keraguan tentang pentingnya teknologi khusus sebagai saluran baru untuk menjangkau masyarakat dengan administrasi publik(Griffin, 2007).

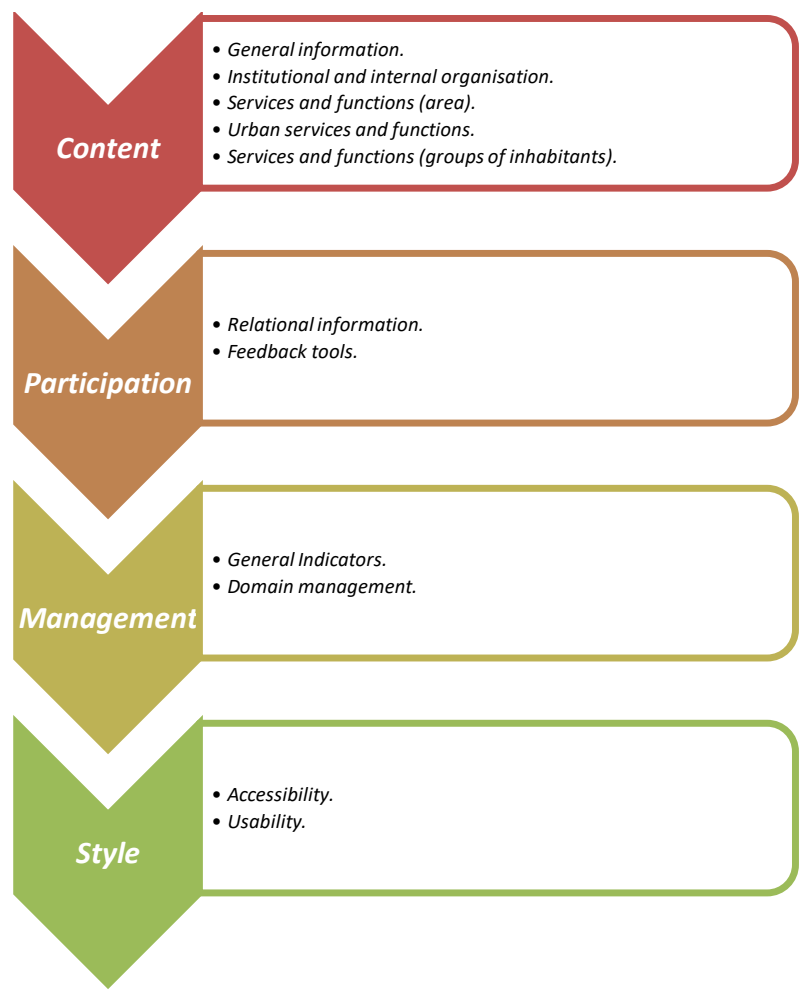

Sumber: Website Dimensions and Orientation To The Citizens, David Griffin (2007).

\section{Gambar 1}

\section{Website Dimensions and Orientation To The} Citizens

Menurut David Griffin (2007),
perkembangan situs web memiliki
beberapa dimensi dan indikator yang
membahas tentang pendekatan inisiatif dan
kemajuan. Secara umum, dimensi analisis
situs web memeriksa kemampuan untuk
menyediakan pelayanan publik elektronik
menggunakan saluran elektronik baru.

Deskripsi Proses Inovasi dalam Menciptakan Pelayanan Publik Berkualitas di Nagari Tanjung Haro Sikabu-kabu Padang Panjang

Dalam melaksanakan proses inovasi, tahapan yang dilewati oleh Nagari Tanjung Haro Sikabu-kabu Padang Panjang adalah tahapan pengembangan inovasi yang 
meliputi proses pencarian kebutuhan atau masalah, riset dasar dan aplikatif, pengembangan, komersialisasi, difusi serta adopsi dan konsekuensi (Suwarno, 2008). Tahapan ini mengartikan bahwa proses pengembangan inovasi yang terjadi secara terus menerus dan mengalami perkembangan menjadi sebuah siklus inovasi. Proses inovasi di sektor publik mencakup pencarian dan penerapan teknologi baru dalam organisasi, cara-cara baru dan lebih baik dalam memberikan pelayanan dan proses serta sistem manajemen yang baru atau belum di coba(McNabb, 2007). Dalam literatur modern, inovasi memiliki pengertian yang sangat beragam serta banyak perspektif yang mencoba mengartikannya. Inovasi dapat diartikan pengenalan elemen baru ke dalam layanan publik dalam bentuk pengetahuan baru, organisasi baru, dan atau manajemen baru atau keterampilan proses, ini merepresentasikan keberlanjutan dengan masa lalu (Osborne \& Brown, 2012).

Pertama, kebutuhan dan masalah menjadi dasar bagaimana suatu organisasi membutuhkan hal baru untuk menyelesaikan kebutuhan dan masalah. Dasar Nagari Tanjung Haro Sikabu-kabu Padang Panjang dalam melihat kebutuhan atau masalah untuk melaksanakan web OpenSID. Pemerintah Nagari Tanjung Haro Sikabu-kabu Padang Panjang mengartikan kebutuhan dan masalah yang dihadapi dalam melaksanakan pelayanan publik dengan menghadirkan web OpenSID sebagai solusi masalah yang dihadapi. Mengenali kebutuhan atau masalah dapat dilakukan melalui proses politik. Begitu pun dengan cara Nagari Tanjung Haro Sikabu-kabu Padang Panjang menghadirkan web OpenSID menjadi prioritas hingga dapat dimasukkan ke dalam RPJM Nagari yang mendapat persetujuan dari unsur-unsur Pemerintahan Nagari.

Kedua, inovasi dalam sektor publik pada umumnya selalu identik dengan teknologi. Dalam hal ini pengertian teknologi adalah sebuah rancangan untuk langkah instrumental mengurangi ketidakpastian dalam hubungan sebabakibat dalam mencapai tujuan yang dikehendaki. Maka dari itu, riset dasar dan aplikatif menjadi penting untuk melaksanakan inovasi sektor publik. Pemerintah Nagari mencari aplikasi yang cocok dengan kebutuhan nagari dalam memberi informasi dan pelayanan kepada masyarakat. Keinginan nagari dalam membangun web nagari dimulai dari mencari cara bagaimana membuat web nagari yang akan melibatkan pihak swasta.

Setelah Operator Nagari menemukan jalan keluar dalam membuat web nagari, maka proses bagaimana belajar membuat web OpenSID tersebut menjadi penting dalam melaksanakan inovasi sektor publik. Proses yang dilaksanakan Operator Nagari tersebut merupakan peran utama hingga inovasi di Nagari Tanjung Haro Sikabukabu Padang Panjang dapat terlaksana. Dengan mengadopsi aplikasi OpenSID memberikan kemudahan Pemerintah Nagari melakukan pelayanan suratmenyurat karena data kependudukan tersimpan dalam aplikasi OpenSID sehinga hanya membutuhkan waktu sedikit dalam melakukan pelayanan.

Ketiga, tahap selanjutnya yang terjadi dalam inovasi sektor publik adalah sebuah pengembangan. Pengembangan sebuah inovasi adalah proses meletakkan ide-ide baru ke dalam bentuk yang diharapkan dapat menjawab kebutuhan. Begitu juga dalam penerapan web OpenSID, Pemerintah Nagari juga 
Publik (Jurnal Ilmu Administrasi) Vol 8 (1), Juni 2019

melakukan pengembangan terhadap web agar pelaksanaannya sesuai dengan kebutuhan Nagari Tanjung Haro Sikabukabu Padang Panjang. Pemerintah Nagari Tanjung Haro Sikabu-kabu Padang Panjang melakukan pengembangan dalam penerapan web OpenSID. Pengembangan yang dilakukan oleh nagari berkaitan dengan kebutuhan nagari untuk menghadirkan informasi sesuai peraturan perundangan. Pengembangan ini bertujuan agar web OpenSID yang dibangun oleh nagari merupakan cerminan dari kondisi yang terjadi di Nagari Tanjung Haro Sikabu-kabu Padang Panjang.

Keempat, setelah pengembangan yang dilakukan oleh nagari, tahap selanjutnya adalah komersialisasi. Komersialisasi dalam sektor publik dapat dianalogikan sebagai tahapan penyebarluasan inovasi. Pemerintah Nagari Tanjung Haro Sikabu-kabu Padang Panjang melakukan sosialisasi penerapan web OpenSID. Sosialisasi Sistem Informasi Desa "OpenSID" dihadiri oleh Wali Nagari dan Operator Nagari Undangan di Kabupaten Lima Puluh Kota beserta Camat Luak dan Diskominfo Kabupaten Lima Puluh Kota. Dalam acara ini, Pemerintah Nagari Tanjung Haro Sikabu-kabu Padang Panjang mengundang Penggiat OpenSID yang berasal dari Yogyakarta untuk menjadi narasumber yang akan menjelaskan OpenSID sebagai sistem informasi desa dan manfaat penggunaannya untuk nagari. Proses ini termasuk dalam tahap komersialisasi yang dilakukan oleh pemerintah nagari dalam melaksanakan penyebarluasan inovasi.

$$
\text { Kelima, Difusi dan Adopsi }
$$
merupakan tahapan menghadirkan inovasi di berbagai tempat. Pengenalan inovasi yang dilakukan dan menentukan pengaplikasian inovasi dapat digolongkan dalam difusi dan adopsi. Pemerintah
Panjang mengajarkan pemakaian OpenSID ke nagari-nagari lain. Proses mengajarkan OpenSID ini bertujuan agar nagari-nagari juga bisa mengadopsi pemakaian OpenSID di nagari masing-masing.

Keenam, Konsekuensi adalah tahap yang dapat mengetahui apakah masalah atau kebutuhan yang diidentifikasi pada awal pengembangan inovasi sudah terjawab atau belum. Seringkali masalahmasalah atau kebutuhan-kebutuhan baru muncul apabila telah dilaksanakan. Permasalahan yang timbul akibat penggunaan web OpenSID belum ada. Kendala yang sering ditemui oleh perangkat nagari beru pada jaringan internet yang sering terganggu. Evaluasi yang dilakukan untuk menemukan permasalahan penggunaan web juga belum dilakukan oleh nagari.

Pemanfaatan web OpenSID oleh Nagari Tanjung Haro Sikabu-kabu Padang Panjang yang merupakan bagian dari inovasi. Proses inovasi yang dijalankan Nagari Tanjung Haro Sikabu-kabu Padang Panjang mulai dari proses pencarian kebutuhan atau masalah, riset dasar dan aplikatif, pengembangan, komersialisasi, difusi serta adopsi telah dijalankan oleh nagari, akan tetapi dalam hal konsekuensi yang merupakan penemuan dari masalah baru yang timbul dari pemanfaatan web OpenSID belum berjalan. Peneliti berasumsi dapat dilihat permasalahan baru melalui evaluasi, namun proses evaluasi di nagari belum terlaksana secara terprogram.

\section{Analisis Pemanfaatan Web OpenSID dalam Meningkatkan Pelayanan Publik di Nagari Tanjung Haro Sikabu-kabu Padang Panjang}

Bentuk usaha yang dilakukan oleh pemerintah Nagari Tanjung Haro Sikabukabu Padang Panjang dalam mengupayakan peningkatan pelayanan 
kepada masyarakat yakni dengan menghadirkan web nagari. Pembuatan web nagari merupakan gagasan dan ide dari Wali Nagari Tanjung Haro Sikabu-kabu Padang Panjang dengan melihat kebutuhan dari nagari. Pemerintah Nagari Tanjung Haro Sikabu-kabu Padang Panjang ingin perbaikan dalam urusan pelayanan publik kepada masyarakat agar dapat menerima pelayanan yang berkualitas. Kerena pelayanan publik yang diberikan kepada masyarakat sesuai dengan peraturan perundang-undangan diharapkan mampu memberikan kepuasan kepada masyarakat, sehingga pelayanan publik dapat disebut pelayanan yang berkualitas. Pelayanan publik yang diberikan kepada masyarakat sesuai dengan peraturan perundangundangan diharapkan mampu memberikan kepuasan kepada masyarakat, sehingga pelayanan publik dapat disebut pelayanan yang berkualitas. Pelayanan publik yang berkualitas haruslah dapat memenuhi beberapa unsur yakni transparansi, akuntabilitas, kondisional, partisipatif, kesamaan hak, dan keseimbangan hak dan kewajiban(Sinambela, 2006). Terlihat dalam pemanfaatan web OpenSID yang memberikan kemudahan masyarakat memperoleh informasi dan pelayanan tercatat peningkatan masyarakat yang mengakses pelayanan di nagari yang dapat dilihat dari tabel 1 berikut

Tabel 1

Jumlah Masyarakat Mengakses Layanan Surat Tahun 2017-2018

\begin{tabular}{ccc}
\hline No & Tahun & Jumlah \\
\hline 1. & 2017 & 1011 \\
2. & 2018 & 1219 \\
\hline
\end{tabular}

Sumber: Olahan Peneliti Tahun 2019

Berdasarkan tabel 1, terjadi peningkatan pelayanan surat menyurat yang dilakukan masyarakat di Kantor Wali
Nagari. Peningkatan pelayanan setalah penerapan OpenSID yang dilakukan di nagari mencapai 20\%. Pelayanan surat menyurat yang dilakukan di nagari berupa surat pengantar, surat keterangan, surat permohonan, surat domisili dan lain-lain yang dibutuhkan masyarakat. Berikut merupakan analisis pemanfaatan web OpenSID untuk meningkatkan pelayanan publik di Nagari Tanjung Haro Sikabukabu Padang Panjang.

Pada bagian variabel konten yang membahas tentang informasi umum, lembaga-lembaga dan organisasi internal, layanan dan fungsi, menghadirkan informasi tentang gambaran umum nagari. Variabel konten memungkinkan masyarakat memperoleh informasi baik itu tentang Pemerintah Nagari maupun masyarakat. Konten merupakan sarana bagi nagari memberikan informasi yang dapat meningkatkan kepercayaan masyarakat terhadap nagari, sehingga informasi yang dihadirkan dalam web dapat berupa informasi uptodate sehingga informasi dapat dipercayai masyarakat.

Pada pemberian informasi umum yang dimasukkan ke dalam web OpenSID Nagari Tanjung Haro Sikabu-kabu Padang Pajang telah terdapat berbagai informasi tentang nagari yang bermacam-macam seperti pemandangan, sosial ekonomi informasi, simbol, akses ke nagari, peta dan sejarah. Namun dalam informasi tersebut belum mencantumkan informasi akomodasi dan bangunan-bangunan yang dimiliki oleh Nagari Tanjung Haro Sikabukabu Padang Panjang. Selain itu, penerapan peta secara digital yang ada dalam web belum dimanfaatkan secara maksimal dengan adanya titik-titik koordinat tentang bangunan atau sarana umum di Nagari Tanjung Haro Sikabukabu Padang Panjang. 
Informasi Lembaga-lembaga dan Organisasi internal tegolong lengkap. Tetapi pada penerapan di Nagari Tanjung Haro Sikabu-kabu Padang Panjang masih terdapat informasi-informasi lama atau belum diperbaharui sesuai dengan keadaan di nagari seperti steruktur nagari. Pada indikator lembaga-lembaga dan organisasi internal, dalam upaya nagari meningkatkan kualitas pelayanan publik merupakan penyokong utama. Informasi yang peraturan internal, sumber daya manusia, anggaran, diagram alur dan struktur organisasi.

Lembaga-lembaga dan organisasi internal memberikan kemudahan bagi nagari dalam melakukan tranparansi kepada masyarakat. Transparansi yang dimaksud adalah proses pelayanan publik yang dilakukan oleh penyelenggara pelayanan semata-mata bertujuan untuk memenuhi kebutuhan masyarakat. Sebagai penyelenggara pelayanan, tuntutan bagaimana menghadirkan informasi dan pelayanan untuk masyarakat membutuhkan transparansi agar pelayanan bersifat terbuka, mudah dan dapat diakses oleh semua pihak yang membutuhkan dan disediakan secara memadai serta mudah dimengerti.

Layanan dan fungsi kelompok penduduk pada dasarnya data kependudukan yang dimiliki oleh Pemerintah Nagari dapat dimanfaatkan dalam upaya melakukan pelayanan publik berkualitas. Dalam memanfaatkan data kependudukan, pemerintah nagari dapat mengetahui kondisi dari masyarakatnya. Informasi kependudukan yang disediakan dalam web OpenSID berupa area, organisasi dan kelompok penduduk. Dengan mengetahui kondisi masyarakat, Pemerintah Nagari diharapkan mampu menghadapi setiap kondisi atau kebutuhan dihadirkan berupa kegiatan nagari,

yang dihadapi saat melakukan pelayanan publik.

Pada dasarnya, pelayanan publik yang berkualitas mempu kondisional dalam artian sesuai dengan kondisi dan kemampuan pemberi dan penerima pelayanan dengan tetap berpegang pada prinsip efisiensi dan efektivitas. Pemerintah Nagari Tanjung Haro Sikabukabu Padang Panjang secara konsisten menghadirkan informasi kepada masyarakat. Usaha-usaha yang dilakukan Pemerintah Nagari dalam memberikan informasi kepada masyarakat bukan hanya melalui web OpenSID, tetapi juga dengan kesiapan aparatur nagari yang ada di Kantor Wali Nagari.

Pembahasan partisipasi, bukan hanya pemberian sarana dan prasarana. Pemerintah nagari seharusnya juga dapat merubah kultur masyarakat agar dapat lebih terbuka dalam penyampaian aspirasi sehingga sarana dan prasarana yang telah diberikan dapat dimanfaatkan masyarakat. Pelaksanaan pelayanan publik bukan hanya melibatkan pemerintah di dalamnya seperti Informasi relasional, tetapi juga terdapat masyarakat sebagai penerima pelayanan. Sebagai proses pemenuhan kebutuhan masyarakat, pelayanan publik diharapkan mampu mendengar aspirasi dan harapan masyarakat. Partisipasi menjadi penting dalam mendorong peran serta terhadap penyelenggaraan pelayanan publik dengan memperhatikan aspirasi, kebutuhan dan harapan masyarakat. Pendekatan partisipasitif merupakan sebagai strategi pembangunan dan proses penentuan keputusan publik, hal ini sangat bergantung pada kesadaran masyarakat untuk mau melibatkan diri dalam proses pembangunan (Akbar,MF, Suprato,S \& Surati,2018).

Informasi relasional menawarkan kepada masyarakat yang mengunjungi web OpenSID nagari juga dapat memperoleh Copyright ( ) 2019, Publik (Jurnal Ilmu Administrasi), Under the license CC BY-SA 4.0 ISSN: 2301-573X (Print), ISSN: 2581-2084 (Online) 
informasi tentang lembaga-lembagai lain di nagari hingga tingkat pemerintah lainnya. Informasi relasional yang disediakan berupa akses ke lembagalembaga nagari dan lembaga lain yang memiliki sinergi dengan Pemerintah Nagari. Berikutnya web OpenSID juga menyediakan alat umpan balik berupa berita, forum, survey dan komentar. Dalam hal ini, web OpenSID menyediakan sarana bagi masyarakat dengan tingkat kebutuhan informasi yang beragam.

Pemenuhan kebutuhan informasi yang beragam menandakan bahwa web telah memberikan pelayanan publik sesuai kondisional. Pelayanan publik yang berkualitas memiliki salah satu unsur yaitu kondisonal. Pemerintah Nagari Tanjung Haro Sikabu-kabu Padang Panjang terus berusaha meningkatkan partisipasi masyarakat dalam menjalankan kegiatankegiatan yang dilaksanakan di nagari. Pemberian sarana dan prasarana tentu memberi efek kepada keaktifan masyarakat dalam menyampaikan masalah dan kebutuhan yang dirasakan oleh masyarakat.

Belum maksimalnya penggunaan teknologi informasi di Pemerintah diakibatkan karena masalah sumber daya manusia. Penyediaan infrastruktur teknologi informasi akan tidak dimanfaatkan secara optimal tanpa didukung SDM yang baik dan akan berakibat pada kinerja yang kurang baik (Catur \& Karis, 2011). Pelaksanaan manajemen dalam penerapan OpenSID di Nagari Tanjung Haro Sikabu-kabu Padang Panjang, baik itu manajemen secara umum dan manajemen domain merupakan usaha nagari dalam memberikan kepastian untuk melakukan pelayanan publik berkualitas. Ketika masyarakat memperoleh efek positif dari manajemen yang dilakukan oleh Pemerintah Nagari, maka manajemen yang dilaksanakan torgolong berhasil. Manajemen yang dilakukan nagari dengan menghadirkan pengelola web yang diserahkan pada Pejabat Pengelola Informasi dan Dokumentasi (PPID), berita terbaru, pembaharuan pada web OpenSID dan syarat bagi masyarakat untuk berpeluang ditanggapi dengan landasan undang-undang. Hal ini menandakan dengan adanya manajemen yang baik dilakukan Pemerintah Nagari, memberikan efek terhadap upaya Pemerintah Nagari Tanjung Haro Sikabu-kabu Padang Panjang meningkatkan kualitas pelayanan publik melalui pemanfaatan web OpenSID nagari.

Dengan demikian, membentuk PPID Nagari dan melakukan pekerjaan sesuai peraturan memberikan jaminan bagi pemerintah dan masyarakat nagari kejelasan tentang hak dan kewajiban masing-masing. Dalam melaksanakan pelayanan publik, keseimbangan hak dan kewajiban merupakan hal yang patut di perhatikan. Hal itu dikarenakan dalam penyelenggaraan pelayanan publik, tentu pemberi dan penerima pelayanan memiliki hak dan kewajiban masing-masing. Terpenuhinya hak dan kewajiban masingmasing antara pemberi dan penerima pelayanan bertujuan agar mempermudah pelayanan dan menciptakan pelayanan yang berkualitas. Pemerintah Nagari Tanjung Haro Sikabu-kabu Padang Panjang telah menjalankan tugas nagari sesuai dengan prosedur yang telah ditetapkan. Apabila masyarakat juga melaksanakan tugasnya sebagai penerima layanan, maka pelayanan publik yang dimaksud dapat berjalan dengan lancar dan selesai dengan cepat sehingga dapat meningkatkan kualitas pelayanan. 


\section{Available Online at http://journal.umgo.ac.id/index.php/Publik \\ Publik (Jurnal Ilmu Administrasi) Vol 8 (1), Juni 2019}

Pada bagian variabel gaya yang terbagi dalam aksesibilitas dan kegunaan dimaksudkan untuk memfasilitasi berbagai macam masyarakat dan kesiapan Pemerintah Nagari dalam melakukan pelayanan publik berkualitas. Pelaksanaan aksesibilitas dan kegunaan yang dilakukan nagari menyokong bagaimana pelayanan publik dapat memberikan kesamaan hak bagi satiap masyarakat dalam melakukan pelayanan publik. Nagari Tanjung Haro Siakabu-kabu Padang Panjang berusaha untuk memberikan pelayanan yang mengutamakan kesamaan hak bagi setiap orang yang memiliki kepentingan di nagari. Kerena kesamaan hak merupakan hal serius yang harus diperhatikan dalam melakukan pelayanan publik.

Kesamaan hak bertujuan agar setiap pelayanan yang diberikan oleh penyelenggara pelayanan publik kepada masyarakat dapat berjalan dengan adil tanpa pembedaan satu dan lainnya. Selain itu, kesamaan hak juga diartikan sebagai pelayanan yang tidak diskriminatif dalam arti tidak membedakan suku, ras, agama, golongan, gender dan status ekonomi. Namun dalam pemanfaatan web OpenSID, nagari belum menyadari pentingnya aksesibilitas yang terdiri dari penggunaan berbagai bahasa, pengguna khusus, subyek dan penggunaan ukuran huruf serta latarbelakang pada web. Akan tetapi usaha nagari dalam menghadirkan alat yang dibutuhkan dalam pemanfaatan web OpenSID harus dipertimbangkan sebagai usaha dalam pemberian pelayanan publik yang mengutamakan kesamaan hak. Sbegitupun dengan hadirnya website map yang disusun secara lengkap sehingga pengunjung dapat memperoleh informasi yang telah dikelompokkan dengan mudah.

Dengan demikian, pelayanan publik yang diselenggarakan di Nagari Tanjung Haro Siakabu-kabu Padang Panjang berusaha untuk menberikan pelayanan Copyright ( $)$ 2019, Publik (Jurnal Ilmu Administrasi), Under the license CC BY-SA 4.0 ISSN: 2301-573X (Print), ISSN: 2581-2084 (Online) yang mengutamakan kesamaan hak bagi setiap orang yang memiliki kepentingan di nagari, sehingga dengan tidak membedabedakan perlakuan pelayanan terciptalah pelayanan yang jauh dari diskriminatif. Pelayanan secara online yang dilakukan melalui web OpenSID juga memberikan efek kepada pelayanan yang dilakukan di Nagari Tanjung Haro Sikabu-kabu Padang Panjang. Pelayanan yang dilaksanakan secara online mengurangi proses tatap muka antara pemberi dan penerima layanan, sehingga setiap orang yang membutuhkan pelayanan memiliki potensi diperlakukan sama.

\section{PENUTUP}

\section{Kesimpulan}

Berdasarkan uraian yang telah diulas di atas, maka dapat disimpulkan bahwa Pemanfaatan web OpenSID di Nagari Tanjung Haro Sikabu-kabu Padang Panjang masih tergolong baru di Kabupaten Lima Puluh Kota dan merupakan inisiatif (inovasi pelayanan publik) nagari. Selanjutnya untuk dapat memanfaatkan web OpenSID, nagari telah melewati beberapa tahapan proses inovasi sektor publik. Pemanfaatan web OpenSID dalam peningkatan pelayanan publik telah berjalan dengan baik, dapat dilihat dari dimensi analisis web sektor publik.

Pemanfaatan web OpenSID telah memiliki informasi yang bermacammacam dan dikelola baik dengan adanya PPID Nagari Tanjung Haro Sikabu-kabu Padang Panjang. Dampak pelayanan publik yang dapat dirasakan dari pemanfaatan web OpenSID adalah dengan kemudahan memperoleh informasi nagari, informasi proses pelayanan publik dan pelayanan publik yang dapat diselesaikan dengan cepat karena data kependudukan yang telah ada dalam server OpenSID. Namun, dalam pemanfaatan web OpenSID masih 
belum berjalan maksimal. Hal ini dikarenakan beberapa informasi yang terdapat dalam konten merupakan informasi yang tidak up to date dan beberapa informasi belum ada. Selain itu, dalam pemanfaatan web OpenSID masih belum disadari pentingnya aksesibilitas karena web OpenSID memiliki potensi dikunjungi oleh masyarakat dengan berbagai macam kebutuhan

\section{Saran}

Kepada pihak terkait diharapkan dapat memberikan perhatian lebih khususnya dalam penambahan alat maupun sarana dalam menunjang maksimalnya web OpenSIG di Nagari Tanjung Haro Sikabu-kabu Padang Panjang, untuk meningkatkan kualitas pelayanan khususnya dalam bidang inovasi layanan.

\section{DAFTAR PUSTAKA}

Akbar, MF, Suprapto, S., \& Surati, S. (2018). Partisipasi Masyarakat Dalam Perencanaan Pembangunan di Desa Jatimulya Kabupaten Boalemo.Publik (Jurnal Ilmu Administrasi), 6 (2), 135-142.

doi:http://dx.doi.org/10.31314/pjia.6.2 $.135-142.2017$

Caldas, M. P. (2009). Research design: qualitative, quantitative, and mixed methods approaches. Revista de Administração Contemporânea. https://doi.org/10.1590/s141565552003000100015

Catur, P. Y. T., \& Karis, W. (2011). Model Penggunaan Teknologi Informasi Dan Kinerja Pegawai Kelurahan Menuju Terwujudnya E-Government. 2011(Semantik).

Crozier, G., Denzin, N., \& Lincoln, Y. (1994). Handbook of Qualitative Research. British Journal of Educational Studies. https://doi.org/10.2307/3121684

Fahrur, R. (2017). Pengembangan website dan sistem informasi desa di kabupaten tulungagung. 02, 107-112.

Github.com. (2018). Peran dan Manfaat Sistem Informasi Desa. Retrieved from https://github.com/OpenSID/Op enSID/wiki/Perandan Manfaat Sistem-Informasi-Desa

Griffin, D. (2007). Developments in egovernment. Amsterdam: IOS Press.

Indrajit, R. E. (2005). E-Government In Action: Ragam Kasus Implementasi Sukses di Berbagai Belahan Dunia. Yogyakarta: Andi Offset.

Limapuluhkota.go.id. (2018). Launcing Standar Pelayanan Minimal Digital dan Media Informasi Publik Berbasis Website. Retrieved from http://www.limapuluhkotakab.go.id/b erita-launching-standar-pelayananminimal-digital-dan-media-informasipublik-berbasis-website.html

McNabb, D. E. (2007). Knowledge management in the public sector: a blueprint for innovation in government. October.

Miles, M.B \& Huberman, A. . (1994). An expanded sourcebook: Qualitative data analysis (2nd Edition). In Sage Publications. https://doi.org/10.1016/ 0149-7189(96)88232-2

Muluk, K. (2008). Knowledge Management: Kunci Sukses Inovasi Pemerintah Daerah. Malang: Bayumedia Publishing.

Mohi, WK., \& Mahmud, I. (2018). Kualitas Pelayanan Publik di Desa Potanga Kecamatan Boliyohuto Kabupaten Gorontalo. Publik (Jurnal Ilmu Administrasi), 6(2), 102-110. doi:http://dx.doi.org/10.31314/pjia.6.2 $.102-110.2017$

Nunik, H. (2016). Citalinuabdi: Upaya 
Yang Bermakna. 01, 48-57.

Osborne, S. P., \& Brown, K. (2012). Managing change and innovation in public service organizations. In Managing Change and Innovation in Public Service Organizations. https://doi.org/10.4324/97802033911 29

Ramdhani, A., \& Ramdhani, M. A. (2017). Konsep Umum Pelaksaan Kebijakan Publik. In Jurnal Publik. https://doi.org/10.1109/ICMENS.200 5.96

Satriya, E. (2006). Pentingnya Revitalisasi E-Government Asisten Deputi 5 / V Deputi Bidang Koordinasi Infrastruktur dan Pengembangan Wilayah Kementerian Koordinator Bidang Perekonomian Gedung Induk, Lt III Jl . Lapangan Banteng Timur 24 , Jakarta , 10710 , Indonesia. 3843.

Sinambela, P. (2006). Reformasi Pelayan

Publik: Teori Kebijakan dan Implementasi. Jakarta: Bumi Aksara. Suara.com. (2018). Kementrian PAN-RB Luncurkan Tujuh Inovasi eGovernment. Retrieved from https://www.suara.com/news/2017/10 /04/121554/kemenpan-rb-luncurkane-goverment

Suwarno, Y. (2008). Inovasi di Sektor Publik. Jakarta: STIA-LAN Press. 